\title{
OTENTISITAS PENERAPAN ASURANSI SYARIAH DI INDONESIA
}

\author{
Nanda Siti Hardyanti \\ Fakutas Syariah dan Hukum \\ Universitas Islam Negeri (UIN) Sunan Kali Jaga Yogyakarta \\ Email : nandasitihardiyantii@gmail.com
}

\begin{abstract}
Insurance sharia based on the cooperation, responsibities, guarantees, protection and assistance among groups of participants. Islamic Insurance (takaful) is considered as cooperative or mutual insurance, where members contribute to pay sum of money or premiums to insurance companies. This study aims to find out the application of Islamic insurance in Indonesia after the law namber 40 of 2014 concerning insurance. This type of research is librabry research. Primary data used are law Number 40 of 2014 corcerning insurance, law number 2 of 1992 KUHD and DSN-MUI fatwa. While the secondary data used is other literature in accordance with the research. The results of this study are summarized as follows: (1) Sharia insurance is an effort to help one another among a number of people/parties through investments in asset and/tabarru" which periode a pattern of returns to deal with certain risks through an agreement in accordance with sharia, with a risk sharing system. (2) The authenticity of sharia insurance in Indonesia is needed by strengthening all Islamic insurance products to run in accordance with sharia privisions, in this case the sharia supervisiory board is an important part in carrying out strict supervision of the activities of sharia insurance institutions. Islamic insurance is a solution to answer Muslim needs for the importance of future planning with halal transactions.
\end{abstract}

\section{Key Words: Authenticity, Implementation Sharia Insurance, Risk Sharing}

\section{Pendahuluan}

Dalam prinsip syariah hukum-hukum muamalah (trransaksi bisnis) adalah bersifat terbuka, artinya Allah Swt dalam al-Qurean hanya memberikan aturan secara garis besarnya saja. Selebihnya bersifat terbuka bagi ulama mujtahid untuk mengembangkannya melalui ijtihad selama tidak bertentangan dengan al-Qurean dan hadis. Di era moderenitas saat ini, banyak prodak muamalat yang berkembang, sejalan dengan itu maka diperlukan adanya sandaraan sebagai tempat kembali ( $m a r " j a)$ dalam menentukan hukum pada suatu transaksi muamalah, seperti yang berkembang saat ini yakni asuransi syariah.

Kehidupan di dunia penuh dengan ketidakpastian dan resiko, mulai dari resiko sakit, kecelakaan, bahkan berujung pada kematian karena resiko seperti kematian tidak bisa dihindari, oleh sebab itu untuk mengatasi permasalahan hidup tersebut manusia dituntut untuk merencanakan masa depan secara komprehensif. Salah satu cara untuk dapat menikmati masa depan yang lebih baik dan berkecukupan dari sisi materi diperlukan tabungan yang mampu meminimalkan resiko tersebut yang pada umumnya disebut dengan tabungan asuransi. 
Kajian asuransi dalam hukum Islam merupakan hal yang baru, dan belum pernah ditemukan dalam literatur fiqih klasik. Pembahasan asuransi dalam wilayah kajian ilmu-ilmu ke-Islaman baru muncul pada fase lahirnya ulama kontemporer. Ada pertanyaan umum yang kerap dilontarkan masyarakat awam: mengapa kita harus berasuransi? Dalam menejemen keuangan kini, asuransi menjadi sebuah pertimbangan sebagai salah satu ikhtiar perencanaan keuangan sekaligus upaya menghilangkan, menghindari, bahkan memperkecil risiko yang mungkin terjadi pada waktu tertentu.

Pertentangan dan penolakan terhadap asuransi juga sering muncul dikarenakan ada kalangan yang memandang asuransi sama dengan mendahului takdir Allah Swt. Mengingat pada praktek asuransi konvensional yang disinyalir terdapat unsur-unsur yang bertentangan dengan syari'ah Islam, seperti maisir, gharar, riba, dzalim dan sebagainya.

Oleh karenanya, perlu pembahasan yang meluruskan asumsi masyarakat tersebut terhadap asuransi berbasis syariah. Tanpa bermaksud mendahului takdir, asuransi dapatlah diniatkan sebagai ikhtiar persiapan untuk mengahadapi kemungkinan terjadinya risiko. Oleh karena itu, Islam pun memberi jalan sehingga asuransi juga bisa menjadi ikhtiar untuk saling menolong di antara sesama Muslim atau bahkan sesama manusia.

Secara ekspilit, dalam al-Quran terdapat ayat yang menyatakan pentingnya perencanaan dalam pekerjaan dan masa depan. Dalam Qs. al-Hasyr ayat 18 Allah berfirman: “Wahai orang-orang yang beriman, bertakwalah kepada Allah dan hendaklah setiap orang memperhatikan apa yang telah diperbuatnya untuk hari esok (masa depan), dan bertakwalah kepada Allah. Sungguh, Allah Maha mengetahui terhadap apa yang kamu kerjakan"1

Secara umum, konsep asuransi merupakan persiapan yang dibuat oleh sekelompok orang yang masing-masing menghadapi kerugian kecil sebagai sesuatu yang tidak dapat diduga. Apabila kerugian itu menimpa salah seorang dari mereka yang menjadi anggota perkumpulan itu, maka kerugian itu akan ditanggung bersama oleh mereka. Masalahnya, cukup sering terjadi penolakan dari beberapa kalangan terhadap praktek asuransi konvensional yang disinyalir terdapat unsur-unsur yang bertentangan dengan syari'ah Islam, seperti maisir, gharar, riba, dzalim dan sebagainya.

Allah Swt mengatur tata kehidupan kedalam dua bidang hukum yaitu:

1. Fikih ibadah, dalam arti khusus atau disebut juga dengan kaidah ibadah murni, mengatur cara hubungan langsung manusia dengan Tuhannya;

2. Fikih muamalah, yang mengatur hubungan manusia dengan manusia lain dan benda dalam masyarkatnya." "Hukum asal dalam muamalah adalah boleh kecuali ada dalil

${ }^{1}$ Departemen Agama RI, Al-Qur"an dan Terjemah, (Bandung: Sygma, 2007), h. 548.

2 uhammad Faruq Nabhan, al-Madkhal Li al-Tasyri" al-Islam, (Bairut: Libanon, Dar al Qalam: 1981), 11. Dalam Abdul Manan, Reformasi hukum Islam di Indonesia, (Jakarta: Rajawali Press, 2005), h. 41. 
yang mengaharamkannya". Yang dimaksud dalam kaidah ini adalah bahwa setiap muamalah dan transaksi pada dasarnya boleh, kecuali yang sudah tegas diharamkan oleh Allah Swt, seperti mengakibatkan kemudharatan, riba, tipuan, dan judi. ${ }^{3}$ Dalam hal ini, asuransi pada dasarnya merupakan nilai-nilai kebaikan dengan sistem adanya penanggung dan tertanggung resiko, akan tetapi akad yang dibuat dalam asuransi konvensional tidak memasukkan akad tabarru" sebagai dasar dalam upaya tolong menolong.

Dalam Islam tidak terdapat aturan yang jelas dan tegas yang mengatur praktik tentang asuransi, oleh karenanya perlu diadakan penggalian hukum oleh ulama ${ }^{\text {ee }}$ dengan jalan ijtihad agar sistem asuransi tersebut tidak melanggar norma agama mengingat tujuan asuransi adalah memberikan kemudahan serta kemaslahatan umat. Salah satu upaya untuk mewujudkannya adalah dengan menciptakan produk asuransi yang dijalankan dengan prinsip Islam atau takaful.

Pada prinsipnya, takaful adalah transaksi keuangan berdasarkan prinsip-prinsip kerjasama, tanggung jawab, jaminan, perlindungan dan bantuan antara kelompok peserta, yang mewakili bentuk asuransi mutual. Kontribusi/Sumbangan yang diperoleh dari peserta diakumulasi kedalam dana umum yang disebut dana tabarru" atau dana risiko, yang mana kompensasi atau ganti rugi nantinya akan diberikan kepada peserta yang menderita kerugian. Ini adalah kebijakan saling kerjasama, solidaritas, dan persaudaraan terhadap risiko tak terduga atau bencana, dimana pihak yang terlibat, diharapkan dapat memberikan kontribusi yang benar. ${ }^{4}$

Pada penerapannya, perkembangan asuransi syariah di Indonesia tidak terlepas dari peran lembaga DSN-MUI. Seluruh ruang gerak ekonomi syariah di Indonesia harus mengacu pada fatwah yang dikeluarkan oleh DSN-MUI, ${ }^{5}$ termasuk juga pada industri asuransi syariah. Sebenarnya dalam hukum Islam sendiri masih terdapat pertentangan mengenai halal atau haramnya produk asuransi. Dalam praktek asuransi syariah terkadang juga masih memicu perdebatan dikalangan masyarakat yang beranggapan bahwa asuransi syariah masih belum sepenuhnya sesuai dengan syariat Islam, atau juga mendahului takdir Allah Swt, sehingga batasan antara asuransi non syariah dengan asuransi syariah sangat tipis. Upaya untuk menciptakan industri perasuransian yang lebih sehat, amanah, dan dapat diandalkan secara

${ }^{3}$ Dewan Syariah Nasional selalu menggunakan kaidah ini dalam keputusan-keputusannya. Lihat Himpunan Fatwa DSN Edisi Kedua Tahun 2003, dalam H. A. Djazuli, Kaidah-kaidah Fikih, Hukum Islam Menyelesaikan Masalah yang Praktis, (Jakarta: Kencana Prenadamedia Group, 2006), h. 130.

${ }^{4}$ Mohammad Abdul Hamid, et.al. The Ownership of Islamic Insurance (Takaful) in Malaysia, Inernational Journal of Advances in Management and Economics, (Vol.2, Issue 6, Nov-Dec. 2013), h. 22.

${ }^{5}$ Muhammad Kutub, Ekonomi Syariah dan Lingkungan Hidup (Studi Analisis Fatwa DSN-MUI tentang Pasar Modal dan Pedoman Umum Penerapan Prinsip Syariah di Bidang Pasar Modal), tesis, (Yogyakarta: UIN Sunan Kalijaga, 2017), h. 5. 
umum dapat dilakukan, baik dengan penetapan ketentuan baru maupun dengan menyempurnakan ketentuan yang sudah ada. Asuransi syariah diharapkan dapat mengatasi pertentangan mengenai halal atau haramnya produk asuransi dan dapat diterapkan di Indonesia tanpa menyalahi syariat Islam.

Dengan adanya UU No. 40 Tahun 2014 tentang Perasuransian telah memberikan payung hukum tehadap industri asuransi syariah, pada dasarnya undang-undang tersebut mendorong pembangunan nasional melalui dua pendekatan pembangunan perasuransian yaitu asuransi konvensional dan asuransi syariah dalam satu prodak peraturan perundagan. Dari sinilah, asuransi syariah mengemban tugas membersihkan unsur-unsur yang tidak sesuai dengan syariah terhadap praktik yang dijalankan oleh asuransi konvensional.

\section{Pengertian Asuransi Syari’ah}

Di dalam referensi hukum Islam, asuransi syariah disebut dengan istilah tadhamun, takaful, dan at-ta"min. Kata tadhammun, takaful, dan at-ta"min atau asuransi syariah diartikan dengan "saling menanggung atau tanggung jawab sosial". 6 Dalam bahasa arab asuransi dikenal dengan istilah al-ta"min, penanggung disebut mu"ammin, tertanggung disebut mu"amman lahu atau musta"min. ${ }^{7}$ At-Ta"min memiliki arti memberi perlindungan, ketenangan, rasa aman, dan bebas dari rasa takut, seperti yang terdapat dalam QS. Quraisy ayat 4: artinya "Yang Telah memberi makanan kepada mereka untuk menghilangkan lapar dan mengamankan mereka dari ketakutan". ${ }^{8}$ Maka at-ta"min dapat diartikan pula sebagai seseorang membayar/menyerahkan uang cicilan agar ia atau ahli warisnya mendapatkan sejumlah uang sebagaimana yang telah disepakati, atau untuk mendapatkan ganti terhadap hartanya yang hilang. ${ }^{9}$

Ibrahim Anis mendefinisikan at-ta"min (asuransi) sebagai berikut: "At-ta"min adalah suatu akad yang mewajibkan salah satu pihak, yaitu penanggung (muammin) untuk memenuhi apa yang telah disepakati kepada pihak lain, yaitu tertanggung (musta"min) ketika syarat-syaratnya telah terpenuhi atau telah jatuh tempo, sebagai imbalan atas penyerahan uang iuran tertentu". 10

Sedangkan dalam Undang-Undang Hukum Dagang pasal 246 disebutkan:”Asuransi atau pertanggungan adalah suatu perjanjian, dimana seorang penanggung mengikat diri kepada seorang tertanggung dengan menerima premi, untuk memberikan penggantian

\footnotetext{
${ }^{6}$ Muhammad Syakir Syula, Asuransi Syariah (Life and Generel): Konsep dan Sistem Operasional, Cet I, (Jakarta: Gema Insani Pres, 2004), h. 28.

${ }^{7}$ Wirdyaningsih, dkk, Bank Dan Asuransi Islam di Indonesia, (Jakarta: Kencana, 2005), h. 177.

${ }^{8}$ Departemen Agama RI, Al-Qur'an dan Terjemah, (Bandung: Sygma, 2007), h. 602.

${ }^{9}$ Syula, Asuransi Syariah, h. 28.

${ }^{10}$ Ibrahim Anis, Al-Mu“jam Al-Wasith, Juz I, cet. II, (Kairo: Dar Ihya ${ }^{\text {ee }}$ At-Turats Al-,Arabiy, 1972),
} 
kepadanya karena satu kerugian, kerusakan atau kehilangan keuntungan yang diharapkan, yang mungkin akan dideritanya karena suatu peristiwa yang tak tertentu. ${ }^{11}$

Dengan demikian dapat disimpulkan bahwasanya asuransi merupakan satu cara untuk memelihara manusia dalam menghadapi resiko (ancaman) bahaya yang beragam yang akan terjadi dalam perjalanan kegiatan hidupnya termasuk aktifitas ekonominya. Di dalam Asuransi terdapat suatu persetujuan dimana pihak yang menjamin berjanji kepada pihak yang dijamin, untuk menerima sejumlah uang premi sebagai pengganti kerugian, yang kemungkinan di derita oleh yang dijamin, karena akibat dari suatu peristiwa yang belum jelas. ${ }^{12}$ Paling tidak ada tiga unsur yang terlibat dalam asuransi. Pertama, pihak tertanggung yang berjanji membayarkan uang premi kepada pihak penangung secara sekaligus atau secara angsur. Kedua, pihak pihak penanggung yang berjanji akan membayar sejumlah uang kepada pihak tertanggung secara sekaligus atau secara angsur apabila ada unsur ketiga. Ketiga, suatu peristiwa yang belum jelas terjadi. ${ }^{13}$

\section{Ruang lingkup dan Perkembangan Asuransi Syariah di Indonesia}

Perkembangan asuransi di Indonesia sudah berjalan dengan sangat pesat dan bahkan sudah memasyarakat di Indonesia. Di kalangan umat Islam, ada anggapan bahwa asuransi non syariah yang banyak berkembang tidak Islami, bahkan orang yang melakukan asuransi sama halnya dengan orang yang mengingkari rahmat Allah. Karenanya, munculah gagasan pembentukan asuransi yang islami. Di Indonesia sendiri, asuransi Islam sering dikenal dengan istilah takaful. Kata takaful berasal dari takafalah-yatakafalu, yang berarti menjamin atau saling menanggung. Moh. Ma'sum Billah memaknakan tafakul dengan: "mutual guarantee provided by a group of people living in the same society a defined risk or catastrophe befalling one's life, property or any form of valuable things". 14

Garis hidup dan rezeki manusia sudah ditentukan oleh Allah swt, sebagaimana firmanNya yang artinya: "Dan tidak ada suatu pun makhluk bergerak (bernyawa) di bumi melainkan semuanya dijamin Allah rezekinya”. (QS. Hud ayat 6). “ ...dan siapa (pula) yang memberikan rezekinya kepadamu dari langit dan bumi? Apakah di samping Allah ada Tuhan (yang lain)? ..." (QS. An-Naml ayat 64). "Dan kami telah menjadikan untukmu di bumi keperluan-keperluan hidup, dan (kami menciptakan pula) makhluk-makhluk yang kamu sekali-kali bukan pemberi rezeki kepadanya" (QS. Al-Hijr ayat 20).

${ }^{11}$ R. Subekti dan R. Tjitrosudibio, Kitab Undang-Undang Hukum Dagang, (Jakarta: PT Pradnya Paramita, 1985), h. 74.

${ }^{12}$ Am, \& Ali, H. Asuransi dalam perspektif hukum islam . (Jakarta: Kencana, 2004), h. 58.

${ }^{13} \mathrm{Z}$ Ali, Hukum asuransi syariah, (Jakarta: Sinar Grafika, 2008), h. 1.

${ }^{14}$ Am. Hasan Ali, Asuransi dalam Perspektif Hukum Islam, Suatu Tinjauan Analisis Historis, Teoritis dan Praktis, (Jakarta: Pernada Media, 2004), h. 33. 
Dari ketiga ayat tersebut dapat dipahami bahwa Allah sebenarnya telah menyiapkan segalanya untuk keperluan semua makhluk-Nya, termasuk manusia sebagai khalifah di muka bumi. Manusia masih perlu mengolahnya, mencarinya dan mengikhtiarkiannya. Melibatkan diri ke dalam asuransi, merupakan salah satu ikhtiar untuk menghadapi masa depan dan masa tua. Namun karena masalah asuransi ini tidak dijelaskan tegas dalam nash, maka masalah asuransi dipandang sebagai masalah ijtihadiyah, yaitu masalah yang mungkin masih diperdebatkan dan terjadi perbedaan pendapat.

Asuransi syariah mempunyai akad yang di dalamnya dikenal dengan istilah tabarru" yang bertujuan kebaikan untuk menolong diantara sesama manusia/peserta asuransi lainnya, bukan semata-mata untuk komersial dan akad tijarah. Akad tijarah sendiri adalah akad atau transaksi yang bertujuan komersial. Peranan perusahaan disini hanya sebatas pengelolaan operasional asuransi dan investasi dari dana-dana/kontribusi yang diterima/dilimpahkan kepada perusahaan.

Dalam bentuk akad tabarrue mutabari mewujudkan usaha untuk membantu seseorang, dan hal ini di anjurkan oleh syariat islam, penderma yang ikhlas akan mendapatkan ganjaran pahala yang besar. Selain itu, akad transaksi asuransi syariah mengandung kepastian dan kejelasan sehingga peserta asuransi menerima polis asuransi sesuai dengan apa yang dibayarkan (yang masuk ke rekening peserta) ditambah dengan dana tabarru" dari setiap peserta asuransi. Oleh karena itu, setiap peserta asuransi yang mendapat musibah atau kerugian akan menerima bantuan dalam bentuk ganti rugi terhadap musibah yang dihadapinya. Bantuan dimaksud bersumber dari dana akad tabarrü (hibah).

Landasan teori asuransi Syariah merujuk kepada : (1). Aqila, yaitu saling memikul atau bertanggung jawab untuk keluarganya. (2). Muwala, yaitu perjanjian jaminan, dimana seorang penjamin menjamin seseorang yang tidak memiliki waris dan tidak diketahui ahli warisnya. Apabila orang yang dijamin meninggal, maka penjamin boleh mewarisi hartanya sepanjang tidak ada ahli warisnya. (3). Tanahud, yaitu dua orang atau lebih berserikat membiayai suatu "kebutuhan" dengan saham yang sama.

Secara historis, asuransi tidak pernah ada pada zaman Nabi Muhammad Saw, sahabat dan tabi'in, ia pertama kali terjadi pada tahun $1182 \mathrm{~m}$. ketika orang-orang yahudi diusir dari Prancis, untuk menjamin resiko barang-barang mereka yang diangkut lewat laut. Pada tahun 1680, di London didirikan lembaga asuransi kebakaran karena kebakaran yang terjadi pada tahun 1666 yang menghanguskan sekitar 13 ribu rumah dan 100 buah gereja. Walaupun secara jelas lembaga asuransi tidak dikenal pada periode awal Islam, akan tetapi terdapat bebrapa aktivitas pada kehidupan Rasulullah yang mengarah pada prinsip asuransi. Misalnya konsep “aqilah”, system tersebut telah berkembang pada masyarakat Arab sebelum lahirnya Rasulullah Saw, kemudian pada zaman Rasulullah Saw system aqilah diperaktekkan diantara 
kaum Muhajirin dan Anshar. Sistem aqilah adalah sistem menghimpun para anggota keluarga besar untuk menyumbang dalam suatu tabungan bersama yang dikenal sebagai "kanz". Tabungan ini bertujuan untuk memberikan pertolongan kepada keluarga korban yang terbunuh secara tidak sengaja dan untuk membebaskan hamba sahaya.

Kebutuhan terhadap kehadiran jasa asuransi yang berdasarkan syariah diawali dengan mulai beroperasinya bank-bank syariah. Hal tersebut sesuai dengan UU No. 7 tahun 1992 tentang perbankkan dan ketentuan pelaksanaan bank syariah. Untuk itulah pada tanggal 27 Juli 1993, ikatan Cendekiawan Muslim se-Indonesia (ICMI) melalui Yayasan Abdi Bangsa Tugu Mandiri sepakat memprakarsai pendirian Asuransi Takaful, dengan menyusun Tim Pembentukan asuransi. ${ }^{15}$

Perkembangan asuransi syariah belakangan ini diburuh banyak orang. Kini, hampir semua perusahaan asuransi membentuk unit syariah. Bahkan asuransi asing juga ikut membuka unit syariah. Total penetrasi pasar asuransi syariah di Indonesia hanya sekitar 3\% dari jumlah penduduk. Asuransi syariah mendapatkan porsi sangat kecil atau sekitar 0,015 dari total penduduk atau hanya sekitar 1,5\% dari total pasar asuransi di Indonesia. Sedangkan secara global, premi asauransi syariah saat ini kurang dari $0,1 \%$ dari total premi asuransi global, asuransi syariah sangat berpotensi untuk dapat berkembang pesat dilihat dari seperempat Negara di dunia ini adalah Negara-negara berpenduduk muslim dan di antaranya terdapat negara-negara kaya. ${ }^{16}$

Berdasarkan proyeksi pertumbuhan aset yang disajikan dalam Rencana Bisnis tahun 2018 yang disampaikan seluruh perusahaan asuransi syariah kepada Otoritas Jasa Keuangan (OJK), rata-rata industry asuransi syariah memproyeksikan asetnya akan tumbuh stabil sekitar $15 \%$ pada periode 2018-2019. Proyeksi rencana bisnis industri asuransi syariah untuk tahun 2018 meliputi: rata-rata pertumbuhan aset 2018 sebesar 14,99\%, sementara indusri asuransi jiwa syariah sebesar 18, 04\%, industri asuransi umum syariah sebesar 13,54\%, dan reasuransi syariah sebesar 13,39\%. Proyeksi pertumbuhan aset asuransi syariah yang sebesar $14.99 \%$ dinilai cukup konservatif mengingat pada tahun 2017 realisasi pertumbuhan aset asuransi syariah bisa mencapai $23,65 \%$ year on year. OJK mencatat market share asuransi syariah tahun 2017 sebesar 4,8\%. ${ }^{17}$ Asuransi umum syariah pada kuartal pertama tahun ini tumbuh signifikan. Merujuk pada data OJK, aset asuransi umum syariah per Maret 2018 mencapai Rp. 5,76 triliun, naik 17,5\% dibandingkan periode yang sama pada tahun lalu sejumlah Rp.4.90 triliun.

\footnotetext{
${ }^{15}$ Ghufroon, \& Sofiniyah, Sistem operasional asuransi syariah, (Jakarta: Renaisan, 2005). H. 51

${ }^{16}$ Muhaimmin Iqbal, Asuransi Umum Syariah dalam Praktik, (Jakarta: Gema Insani Press, 2006), h. 1.

${ }^{17}$ www.ojk.go.id diakses 6 November 2018.
} 
Walaupun secara kuantitas, perkembangan asuransi syariah di Indonesia relatif pesat, tetapi pada keyataannya asuransi syariah masih menghadapi beberapa kendala. Hal-hal yang menjadi kendala antara lain, pertama, kurang sosialisasi. Media komuniksai yang digunakan masih terbatas, hal ini tentu saja karena faktor pemodalan. Kedua, keterbatasan tenaga ahli asuransi syariah yang professional. Ketiga, dukungan umat Islam yang masih rendah. Mereka belum menjadikan asuransi syariah sebagai kewajiban dalam praktik muamalat, sehingga motif finansial masih dominan menjadi petimbangan dibandingkan dengan kebutuhan kesesuaian dengan ketentuan hukum Islam. Keempat, dukungan pemerintah belum optimal, terutama dalam hal kendala perundang-undangan yang hingga kini belum terakomidasi secara optimal. $^{18}$

\section{Pendapat Ulama Kontemporer Terhadap Asuransi}

Beberapa pendapat para ulama mengenai hukum asuransi ditinjau dari fiqh Islam yang paling mengemuka, diantaranya:

\section{Pendapat yang Mengharamkan}

Asuransi itu haram dalam segala macam bentuknya, termasuk asuransi jiwa. Pendapat ini dikemukakan oleh Sayyid sabiq, Abdullah al-Qalqii (mufti Yordania), Yusuf Qardhawi dan Muhammad bakhil al-muth"i (mufti Mesir). Alassan utama pengharaman asuransi yaitu premi yang dibayarkan oleh pemegang polis dibayarkan dalam bentuk riba. Dalam literatur lain, Warkum Sumitro menyebutkan alasan-alasan dari kelompok yang mengharamkan asuransi ialah: ${ }^{19}$ (a) Asuransi sama dengan judi. (b) Asuransi mengandung unsur ketidakpastian. (c) Asuransi mengandung unsur-unsur riba/renten. (d) Auransi termasuk jual beli atau tukar menukar mata uang tidak tunai. (e) Asuransi mengandung unsur eksploitasi/pemerasan, karena pemegang polis, apabila tidak bisa melanjutkan pembayaran preminya, akan hilang premi yang sudah dibayar atau dikurangi. (f) Asuransi objek bisnisnya digantungkan pada hidup matinya seseorang, yang berarti mendahului takdir Allah.

Melihat alasan-alasan yang dikemukakan oleh pendapat pertama ini yang mengharamkan asuransi, penulispun setuju, karena asuransi seperti ini bertentangan dengan ajaran Islam dimana praktiknya hanya menguntungkan sebelah pihak saja atau bersifat untung-untungan yang tidak dibenarkan dalam Islam.

2. Pendapat yang Membolehkan

\footnotetext{
${ }^{18}$ Andri Soemitra, Bank \& Lembaga Keuangan Syariah, (Jakarta: Kencana, 2009), h. 286.

19 Warkum Sumitro, Asas-Asas Perbankan Islam dan Lembaga-Lembaga Terkait di Indonesia, (Jakarta: Raja Grafindo Persada, 1997), h. 166.
} 
Pendapat kedua ini diwakili oleh Abd. Wahab Khalaf, Mustafa Akhmad Zarqa (guru besar hukum Islam pada Fakultas Syariah Universitas Syiria), Muhammad Yusuf Musa (guru besar hukum Islam pada Universitas Kairo Mesir, Syekh Muhammad al-Madani (Dekan Universitas al-Azhar), dan Abd. Rahman Isa pengarang kitab al-Muamalah al-Haditsah wa Ahkamuha. Mereka beralasan: (a) Tidak ada Nash (Al-Quran dan Sunnah) yang melarang asuransi; (b) Terdapat kesepakatan dan kerelaan kedua belah pihak; (c) Asuransi menguntungkan kedua belah pihak; (d) Asuransi dapat menanggulangi kepentingan umum, sebab premi-premi yang terkumpul dapat diinvestasikan untuk proyek-proyek yang produktif dan pembangunan; (e) Asuransi termasuk akad madharabah (bagi hasil) antara pemegang polis dengan perusahaan asuransi; (f) Asuransi termasuk koperasi (Syirkah Ta"awuniyah), usaha bersama berdasarkan prinsip tolong-menolong; (g) Asuransi dianalogikan (Qiyaskan) dengan sistem persiun seperti taspen".

Untuk pendapat yang kedua ini, menurut hemat penulis hal ini tidak sepenuhnya dapat dibenarkan jika dalam praktiknya masih terdapat unsur-unsur ketidakpastian maupun untunguntungan, terlebih jika dalam operasionalnya terdapat sistem pemindahan resiko, sebab jika dikatakan asuransi termasuk usaha bersama yang didasarkan pada prinsip tolong-menolong maka seharunya sistem yang digunakan adalah berbagi risiko, sehingga dapat membangun perekonomian ummat, seperti yang dijalankan di asuransi syari'ah pada umumnya. Namun jika praktik asuransinya terbebas dari unsur-unsur tersebut dan mengguunakan sistem berbagi resiko agar sesuai dengan prinsip syariah maka penulis setuju dalam kebolehannya.

3. Asuransi Sosial Boleh dan Komersial Haram

Pendapat ini dikemukakan oleh Muhammad Abzu Zahra (guru besar hukum Islam pada Universitas Kairo). Alasan kelompok-kelompok ketiga ini sama dengan kelompok pertama dalam asuransi yang bersifat komersial (Haram) dan sama pula dengan alasan kelompok kedua, dalam asuransi yang bersifat sosial (boleh)".

Walaupun demikian, masih ada anggapan dari sebagian kalangan bahwa asuransi sama dengan menentang Qadha dan Qadar atau bertentangan dengan takdir. Padahal sesungguhnya tidak demikian, karena pada dasarnya Islam mengakui bahwa kecelakaan, kemalangan, dan kematian merupakan takdir Allah yang tidak dapat di tolak. Hanya saja sebagai manusia diperintahkan membuat perencanaan untuk menghadapi masa depan. Seperti firman Allah dalam QS.Al-Hasyr, ayat 18 : Artinya: “Hai orang-orang yang beriman, bertakwalah kepada Allah dan hendaklah setiap diri memperhatikan apa yang Telah diperbuatnya untuk hari esok (masa depan); dan bertakwalah kepada Allah, Sesungguhnya Allah Maha mengetahui apa yang kamu kerjakan". ${ }^{20}$

\footnotetext{
${ }^{20}$ Departemen Agama RI, Al-Qur"an dan Terjemahnya, h. 548.
} 
Jelas sekali dalam ayat ini kita diperintahkan untuk merencanakan apa yang akan kita perbuat untuk masa depan. Dalam hal ini manusia ditugaskan hanya mengatur bagaimana cara mengelola kehidupannya agar mendapat kebahagiaan dunia dan akhirat. Adapun salah satu caranya adalah dengan menyiapkan bekal untuk kepentingan dimasa akan datang agar segala sesuatu yang benilai negatif, baik dalam bentuk musibah kecelakaan, kebakaran ataupun kematian dapat di minimalisir kerugiannya, karena kemampuan manusia hanya sebatas memprediksi dan merencanakan sesuatu yang belum terjadi serta memproteksi segala sesuatu yang di rasa akan memberikan kerugian dimasa akan datang.

Menurut khallaf, bahwa tujuan umum syar'iah dalam mensyariatkan hukum ialah terwujudnya kemaslahatan umum dalam kehidupan, mendapatkan keuntungan dan menghindari bahaya. Kemaslahatan manusia dalam kehidupan ini terdiri atas beberapa hal yang bersifat kebutuhan pokok (dharuriyyah), kebutuhan (hajiyyah), dan penyempurna (Tahsiniyah). Dalam hal ini keberadaan Asuransi Syariah dapat dikatakan sebagai kebutuhan hajiyyah. Kebutuhan hajiyyah yaitu suatu yang diperlukan oleh manusia dengan maksud untuk membuat ringan, lapang dan nyaman dalam menanggulangi kesulitan-kesulitan kehidupan.

\section{Aturan Hukum dan Penerapan Asuransi Syariah di Indonesia}

Di Indonesia, asuransi syariah diatur dalam UU No. 40 tahun 2014 tentang perasuransian. Menurut UU Nomor 40 tahun 2014 pasal satu, asuransi syariah merupakan kumpulan perjanjian, yang terdiri atas perjanjian antara perusahaan asuransi syariah dan pemegang polis dan perjanjian di antara para pemegang polis, dalam rangka pengelolaan kontribusi berdasarkan prinsip syariah guna saling menolong dan melindungi dengan cara: 1). Memberikan penggantian kepada peserta atau pemegang polis karena kerugian, kerusakan, biaya yang timbul, kehilangan keuntungan, atau tanggung jawab hokum kepada pihak ketiga yang mungkin diderita peserta atau pemegang polis karena terjadinya suatu pristiwa yang tidak pasti; atau 2). Memberikan pembayaran yang didasarkan pada meninggalnya peserta atau pembayaran yang didasarkan pada hidupnya peserta dengan manfaat yang besarnya telah ditetapkan dan/atau didasarkan pada pengelolahan dana. ${ }^{21}$

Selain itu, uraian tentang asuransi syariah juga dikemukakan dalam Fatwah Dewan Syariah Nasional MUI, dalam fatwa DSN No. 21/DSN - MUI/X/2001 tentang pedoman Umum Asuransi Syariah. Dalam ketentuan umum poin 1 disebutkan: "Asuransi syariah (ta"min, takaful, atau tadhamun) adalah usaha saling tolong menolong di antara sejumlah orang/pihak melalui investasi dalam bentuk asset dan/atau tabarru" yang memberikan pola pengembalian untuk menghadapi risiko tertentu melalui akad (perikatan) yang sesuai dengan

\footnotetext{
${ }^{21}$ Undang-undang No.40 Tahun 2014 Tentang Perasuransian.
} 
syariah", ${ }^{22}$ Akad yang sesuai dengan syariah yang dimaksud adalah yang tidak mengandung gharar, perjudian (Maysir), riba, penganiayaan (zhulm), suap (risywah), barang haram dan maksiat. Di dalam asuransi syariah itu sendiri akad yang dilakukan antara peserta dengan perusahaan terdiri dari: akad Mudharabah (bagi hasil), dan akad tarbarru"e (hibah).

Menurut pendapat Hasan Ali menyatakan bahwa: “Akad mudharabah ialah bentuk akad kerjasama antara dua orang atau lebih yang mengharuskan pemilik modal (dalam hal ini nasabah asuransi) menyerahkan sejumlah dana (premi) kepada perusahaan asuransi (mudharib) untuk dikelola. ${ }^{23}$ Dana yang terkumpul oleh perusahaan asuransi diinvestasikan agar memperoleh keuntungan (profit) yang nantinya akan dibagi antara perusahaan dan nasabah asuransi dengan persentase nisbah yang telah disepakati sejak awal perjanjian. Sedangkan apabila usaha tersebut merugi maka kerugian tersebut akan di tanggung sepenuhnya oleh pihak shahibul mal sepanjang hal itu disebabkan oleh resiko bisnis dan bukan karena kelalaian mudharib.

Akad Tabarrue merupakan bentuk transakasi atau perjanjian kontrak yang bersifat nirlaba (not for profit transaction), yakni semua bentuk akad yang dilakukan untuk tujuan kebaikan dan tolong-menolong, bukan semata untuk tujuan komersial ${ }^{24}$ sehingga tidak boleh digunakan untuk bisnis. Pihak yang meniatkan tabarru" tidak boleh mensyaratkan imbalan apapun. Menurut Yusuf Qardhawi, dana tabarru" ini haram untuk ditarik kembali karena dapat disamakan dengan hibah. Jika dalam hal evenement tidak terjadi, maka peserta mengikhlaskan dana yang dimasukannya untuk kepentingan sosial yakni masuk dalam pertanggungan yang sifatnya derma.

Terkait polis, asuransi menerapkan akad tijarah (mudharabah dan mudharabah musytakarah), maka peserta asuransi berkedudukan sebagai pihak penyandang dana (shohibul maal) sedangkan perusahaan asuransi akan bertindak sebagai pengelola dana (mudharib). Dalam asuransi syariah terdapat rukun-rukun akad yang meliputi : (a). Agid, yaitu pihak-pihak yang mengadakan agid (perusahaan dengan peserta). (b). Ma kud ${ }^{\text {ee }}$ alaihi, yaitu sesuatu yang di akadkan atasnya (barang dan bayaran). (c). Sighah (ijab dan Kabul).

Proses hubungan peserta dan perusahaan dalam mekanisme pertanggungan pada asuransi syariah adalah sharing of risk atau "saling menanggung resiko". Apabila terjadi musibah, maka semua peserta asuransi syariah saling menanggung. Dengan demikian, tidak terjadi transfer resiko (transfer of risk) atau "memindahkan resiko" dari peserta ke perusahaan seperti pada asuransi konvensional.

\footnotetext{
2006), h. 127.

${ }^{22}$ M. Ichman Sam, dkk, Himpunan Fatwa Dewan Syari“"ah Nassional, Edisi Ketiga (Jakarta: DSN MUI,

${ }^{23}$ Ali, Asuransi, h. 129.

${ }^{24}$ Burhanuddin, Aspek hukum lembaga keuangan syariah edisi I. (Yogyakarta: Graha ilmu. 2010), h. 140.
} 
Hakikat asuransi syariah adalah saling bertanggung jawab, dan bantu membantu serta saling menanggung penderitaan satu sama lain. Oleh karena itu asuransi diperbolehkan jika dilakukan sesuai syariah, karena prinsip-prinsip dasar syariah mengajak kepada segala sesuatu yang berakibat solidaritas jalinan sesama manusia dan kepada sesuatu yang meringankan bencana mereka, sebagaimana firman Allah Swt dalam Al-Qur'ean surah alMaidah ayat 2 yakni: "Dan tolong-menolonglah kamu dalam mengerjakan kebajikan dan takwa, dan jangan tolonh-menolonglah kamu dalam berbuat dosa dan pelanggaran. Dan bertaqwalah kamu kepada Allah, sesungguhnya Allah amat berat siksa-Nya”.

Dengan demikian, gagasan mengenai tangung-menanggung resiko dalam asuransi takaful tersebut dilakukan atas dasar kebersamaan saling tolong-menolong dalam kebaikan dengan cara masing-masing mengeluarkan dana yang ditujukan untuk menanggung resiko tersebut. ${ }^{25}$ Peranan perusahaan disini hanya sebatas pengelola operasional perusahaan asuransi serta investasi dari dana-dana/kontribusi yang diterima/di limpahkan kepada perusahaan. Perusahaan asuransi syariah memperoleh ujrah (fee) dari pengelolaan dana akad tabarru" (hibah). Perusahaan asuransi syariah hanya bertindak sebagai fasilitator dan mediator proses saling menanggung di antara para peserta asuransi.

Hal inilah salah satu yang membedakan antara asuransi syariah dengan asuransi konvensional, di mana dalam asuransi konvensional tidak terjadi saling menanggung antara perusahaan asuransi dengan peserta asuransi.

\section{Prinsip Asuransi Syariah}

Prinsip dalam asuransi syari'ah yaitu ata'awanu,alal birri wat-taqwa (tolong-menolong kamu sekalian dalam kebaikan dan takwa) dan al-ta"min (rasa aman). Dalam UU Nomor 40 tahun 2014 pasal 1 poin 3 disebutkan bahwa, "prinsip syariah adalah prinsip hukum Islam dalam kegiatan perasuransian berdasarkan fatwa yang dikeluarkan oleh lembaga yang memiliki kewenangan dalam penetapan fatwa di bidang syariah". ${ }^{26}$ Prinsip ini menjadikan para anggota atau peserta asuransi sebagai sebuah keluarga besar yang satu dengan yang lainnya saling menjamin dan menanggung resiko. Hal ini disebabkan transaksi yang dibuat dalam asuransi syari'ah adalah akad takafuli (saling menanggung), bukan akad tabaduli (saling menukar) yang selama ini digunakan oleh asuransi konvensional.

Dalam model asuransi syariah ini tidak ada perbuatan memakan harta manusia dengan batil (aklu amwalinas bilbathil), karena apa yang telah diberikan adalah semata-mata sedekah dari hasil harta yang dikumpulkan. Selain itu keberadaan asuransi syariah akan membawa kemajuan dan kesejahteraan kepada perekonomian umat.

\footnotetext{
${ }^{25}$ Rahmat Husein, Asuransi Takaful Selayang Pandang dalam Wawasan Islam dan Ekonomi, (Jakarta: Lembaga Penerbit FE-UI, 1997), h. 234.

${ }^{26}$ UU No.40 Tahun 2014, Tentang Perasuransian.
} 


\section{Tata Cara dan Operasional Asuransi Syariah}

Adapun ketentuan mengenai akad dalam asuransi adalah sebagai berikut: ${ }^{27}$

1. Akad dalam asuransi

a) Akad yang dilakukan antara peserta dengan perusahaan terdiri atas akad tijarah dan/atau akad tabarru'.

b) Akad tijarah yang dimaksud ayat 1 fatwa DSN MUI adalah mudharabah, sedangkan akad tabarru" adalah hibah;

c) Dalam akad, sekurang-kurangnya harus disebutkan: (1). Hak dan kewajiban peserta asuransi dan perusahaan asuransi; (2). Cara dan waktu pembayaran premi; (3). Jenis akad tijarah dan/atau akad tabarru" serta syarat-syarat yang disepakati, sesuai dengan jenis asuransi yang diakadkan.

2. Kedudukan para pihak dalam akad tijarah dan tabarru" adalah sebagai berikut: a) Dalam akad tijarah (mudharabah) perusahaan bertindak sebagai mudharib (pengelola) dan peserta bertindak sebagai shohibul maal (pemegang polis). b) Dalam akad tabarru" (hibah), peserta memberikan hibah yang akan digunakan untuk menolong peserta lain yang terkena musibah, sedangkan perusahaan bertindak sebagai pengelola dana hibah.

Hubungan antara perusahaan takaful dan peserta mengikatkan diri dalam perjanjian mudharobah dengan hak dan kewajiban sesuai dengan perjanjian. Berbeda dengan asuransi konvensional, arusansi syariah dibangun dengan semangat saling menanggung (takaful), bukan berdasarkan akad pertukaran (tadabbuli).

3. Tata Cara Pengelolaan atau Invetasinya Tidak Boleh Bertentangan Dengan Syariat Islam:

a) Tidak menginvestasikan dananya dengan menggunakan mekanisme bunga/riba. b) Terhindar dari Gharar (ketidakjelasan transaksi); diharamkannya asuransi konvensional karena ketidakjelasan ma"kud alaih (sesuatu yang diadakan) yang meliputi hal-hal yang tidak diketahui secara pasti berapa yang diperoleh (ada ataupun tidak ada, besar maupun kecil), tidak diketahui berapa yang dibayarkan, tidak diketahui berapa peserta akan mampu membayarkannya. Sebagai Contohnya: apabila terjadi klaim, seperti asuransi yang diambil sepuluh tahun dengan pembayaran premi 1.500.000/tahun,

${ }^{27}$ Fatwah DSN MUI NO. 21 DSN/MUI/X/2001 Tentang Pedoman Umun Asuransi Syariah. 
kemudian jika pada tahun kelima dia meninggal dunia, maka pertanggungan diberikan sebesar 15.000.000. Hal ini berarti uang sebesar Rp.7.500.000 yang bukan merupakan cicilan premi selama lima tahun adalah gharar dan tidak jelas dari mana asalnya. Berbeda dengan asuransi syraiah yang sejak awal polis dibuka, sudah diniatkan 95\% premi tabungan dan 5\% diniatkan untuk dana tabarru" (kebajikan derma/sumbangan). c) Terhindar dari Maysir (judi/untung-untungan). Mekanisme asuransi konvensional melahirkan konsep maysir sebagai akibat dari adanya gharar. Dalam asuransi konvensional, maisyir dapat timbul karena ada dua hal yakni: (1). Sekiranya seseorang memasuki satu premi, ada kemungkinan dia berhenti karena alasan tertentu. Jika berhenti di jalan sebelum mencapai refreshing period, dia hanya bisa menerima uangnya kembali sekitar $20 \%$ dan selebihnya hangus. (2). Apabila perhitungan kematian tepat dan menunjukan jumlah polis yang tepat, maka perusahaan akan untung, tetapi jika salah

dalam perhitungan maka perusahaan akan rugi. ${ }^{28}$

Dalam asuransi syariah, meski penerima polis belum mencapai refreshing period sekalipun, bila ia ingin mengambil dananya dikarenakan sesuatu hal, maka itu diperbolehkan karena perusahaan asuransi dalam hal ini adalah sebagai pemgang saham. Sedangkan asuransi yang mendasarkan pada akad tabarru" menggunakan akad hibah, sehingga dalam hal tidak terjadi kejadian yang tidak diinginkan (evenement), maka pemegang polis dengan sukarela menghibahkan dananya kepada perusahaan asuransi untuk dimanfaatkan oleh pemegang polis lain yang mengalami musibah.

Dalam fatwah DSN-MUI NO.21/DSN/MUI/X/2001 tentang Pedoman Umum Asuransi Syariah, disebutkan bahwa Asuransi dengan akad tijarah dapat diubah menjadi akad tabarru" bila pihak yang tertahan haknya, dengan rela melepaskan haknya sehingga menggugurkan kewajiban pihak yang belum menunaikan kewajibannya. Namun jenis akad tabarru" tidak dapat di ubah menjadi akad tijarah.

Prinsip operasional asuransi syariah mempunyai ciri-ciri khas, sebagai berikut:

1. Niat, semangat, tata cara pengelolaan, jenis usaha, dan pengawasan syariah.

${ }^{28}$ Muhammad Firdaus, dkk, Sistem Operaassional Asuransi Syariah, (Jakarta: Renaisan, 2005), h. 25. 
a. Dana asuransi diperoleh dari pemodal dan peserta asuransi di dasarkan atas niat dan semangat persaudaraan untuk saling membantu pada waktu diperlukan.

b. Tata cara pengelolaan tidak terlibat unsur-unsur yang bertentangan dengan Syariat Islam.

c. Jenis asuransi Islam terdiri dari : (1). Asuransi jiwa yang memberikan perlindungan kepada peserta atau ahli warisnya sebagai akibat kematian, dan sebagainya. (2). Asuransi kerugian yang memberikan perlindungan atas kerugian harta benda karena kebakaran, kecurian, dan sebagainya.

d. Terdapat Dewan Pengawas Syariah yang bertugas mengawasi operasional perusahaan agar tidak menyimpang dari tuntunan syariat. Pada asuransi syariah yang perlu mendapat perhatian adalah agar format berbagai perjanjian yang mengikat para pihak dan investasi yang dilakukan perusahaan agar tidak menyimpang dari ketentuan-ketentuan syariah.

2. Modal Saham

Modal saham yang disetor para pemegang saham merupakan modal awal usaha asuransi syariah untuk dibelanjakan bagi kebutuhan awal operasi dan sisanya diinvestasikan sesuai dengan prinsip syariat Islam atas dasar konsep mudharabah.

Berdasarkan jenisnya, asuransi syariah mengadakan dua bidang asuransi yaitu:

Asuransi jiwa/keluarga (life insurance) dan Asuransi umum/kerugian (General insurance).

a. Asuransi jiwa syariah (life insurance) adalah bentuk asuransi yang memberikan perlindungan dalam menghadapi musibah kematian dan kecelakaan atas diri peserta asuransi. Berbeda dengan kerugian yang bersifat umum, bentuk asuransi ini bersifat individu karena jaminan yang diberikan melekat pada diri seseorang.

b. Asuransi umum syariah (General insurance) adalah bentuk asuransi yang memberi perlindungan dalam menghadapi bencana atau kecelakaan atas harta milik peserta asuransi syariah, seperti rumah, kendaraan bermotor, bangunan pabrik, pengangkutan barang, resiko mesin dan sebagainnya. 
Pengelolaan dana pada asuransi keluarga/jiwa secara umum menggunakan dua sistem cara, yaitu: Pengelolaan dana dengan unsur tabungan dan pengelolaan dana tanpa unsur tabungan.

1. Pengelolaan dana dengan unsur tabungan, disebut juga dana investasi dimana setiap peserta wajib membayar sejumlah uang (premi) secara teratur kepada perusahaan. Meskipun perusahaan menetapkan jumlah minimum premi yang bisa dibayarkan, namun pada prinsipnya pembayaran premi tergantung pada kemampuan peserta. Peserta dapat memilih pembayaran, baik bulanan, kuartal, semesteran, maupun tahunan sesuai kemampuan. Melalui sistem ini, setiap premi asuransi yang telah di serahkan kepada perusahaan asuransi akan di masukkan ke dalam dua rekening secara terpisah, yaitu :

a) Rekening khusus Tabarrue (participant"s special account atau sharity account), yaitu rekening yang diniatkan untuk dana kebajikan dan digunakan untuk membayar klaim apabila ada diantara peserta yang ditakdirkan meninggal dunia atau mengalami musibah lainnya.

b) Rekening tabungan peserta (participant"s account), yaitu rekening yang dimiliki oleh para peserta asuransi, rekening tabungan ini selain dapat diinvestasikan (tijarah) juga

dapat di dermakan untuk kebaikan (tabarru)". ${ }^{29}$

Penentuan pembiayaan rekening ini semata untuk berjalannya uasaha perusahaan secara transparan dan menghilangkan keraguan mengenai dari mana dana untuk membayar klaim. Sejak awal peserta sudah diminta untuk menghibahkan 5-30\% uang preminya yang dimasukan kedalam rekening peserta khusus, guna membayar klaim bila terjadi musibah pada sebagian peserta.

Seluruh premi akan disantunkan kedalam kumpulan dana peserta selanjutnya diinvestasikan secara syariah. Keuntungan yang diperoleh akan dibagikan sesuai perjanjian mudharabah (bagi hasil), misalnya70\% dari keuntungan akan diberikan untuk peserta dan $30 \%$ untuk perusahaan. Bagian keuntungan milik peserta $(70 \%)$ akan ditambahkan ke rekening peserta (tabungan) dan rekening khusus secara proporsional. Sedangkan bagian

${ }^{29}$ Anwar S, Hubungan Perjanjian Syariah, (Jakarta: PT.Raja Grasindo Persada, 2007). 98 
keuntungan milik peerusahaan (30\%) akan digunakan untuk membiayai operasional perusahaan. Dengan demikian, rekening tabungan peserta akan dibiayai bila: ${ }^{30} 1$ ). Pertanggungan berakhir; 2) Peserta mengundurkan diri dalam masa perjanjian; 3) Peserta meninggal dunia dalam masa perjanjian.

Sedangkan rekening khusus akan dibayar bila: a) Peserta meninggal dunia dalam masa perjanjian; b) Pertanggungan berakhir dalam hal terdapat net surplus.

2. Pengelolaan dana tanpa unsur tabungan; Premi peserta yang diterima akan dimasukkan ke dalam rekening khusus, yaitu kumpulan dana yang diniatkan untuk tujuan kebajikan (tabarru") guna pembayaran klaim kepada peserta bila terjadi musibah atas harta benda mengalami kerugian. Dana ini juga diinvetasikan secara syariah, dan keuntungan yang diperoleh akan dimasukkan ke kumpulan dana peserta untuk kemudian dikurangi biaya asuransi (klaim). Jika terdapat kelebihan sisa dana maka akan dibagikan kepada peserta dan perushaan menurut prinsip al-mudharabah (bagi hasil), jadi 30\% keuntungan untuk peserta dan 70\% untuk perusahaan. Persentase kedua rekening tersebut ditentukan sesuai dengan kelompok umur peserta syarie`ah dan jangka waktu pertanggungan.

\section{Otentisitas Asuransi Syariah}

Penyelenggaraan asuransi di Indonesia secara umum, baik itu pada asuransi syariah atau pada asuransi konvensional, berdasarkan Pasal 25 UU No. 40 Tahun 2014 tentang Perasuransian, dimana objek asuransi di Indonesia hanya dapat diasuransikan pada perusahaan asuransi dan perusahaan asuransi syariah yang mendapatkan izin usaha dari Otoritas Jasa Keuangan (OKJ).

Pada industri asuransi konvensional, jelaslah bagi kita bahwa asuransi konvensional diharamkan. Adapun prinsip menggunakannya karena alasan dharurat atau hajah tidak bisa diterima dikarenakan hal tersebut bukan satu-satunya pilihan, disamping itu juga kini telah banyak berdiri perusahaan asuransi syarieah. Keadaan dharurat sendiri terjadi jika sesuatu

\footnotetext{
${ }^{30}$ Jeni Sustanti, Pengelolaan Lembaga Keuangan Syariah, (Malang: Empat Dua, 2016), h. 183.
} 
yang tidak dilakukan akan menimbulkan kerusakan besar ataupun kematian. Adapun dalam hal asuransi, tidak terdapat hal-hal demikian.

Masalahnya sekarang apakah puluhan perusahaan asuransi syariah yang berdiri saat ini memang telah menerapkan prinsip-prinsip syariah secara murni? Sikap wara" (kehatihatian) dalam hal ini memang perlu dimiliki oleh setiap muslim, karena mungkin saja ada perusahaan yang kurang murni dalam penerapan prinsip-prinsip syariahnya sehingga masih meragukan (syubhat) disebabkan lebih kentalnya orientasi bisnis dibandingkan kemaslahatannya.

Bagaimana seorang muslim bisa mencermati sebuah perusahaan yang murni menerapkan prinsip syariah atau tidak, tentu bisa dilakukan dengan jalan mempelajari hak dan kewajiban selaku peserta asuransi syariah. Peserta asuransi syariah harus proaktif mencari tahu berbagai informasi berkaitan dengan produk asuransi syariah dan aktif bertanya dalam penawaran produk asuransi syariah yang diberikan oleh perusahaan.

Terlepas dari keraguan yang timbul pada beberapa kalangan, sebenarnya produk atau layanan asuransi syariah sudah diatur sedemikian rupa agar sesuai dengan tuntunan syariah. Pakar ekonomi syariah Muhammad Syakir Sula mengatakan, produk asuransi syariah itu secara umum terbagi dalam dua kategori. Pertama, yang murni tolong-menolong (tabarru"/ta"awun). Kedua, asuransi sekaligus investasi (bisnis). Dia mengungkapkan, ada salah satu kelompok yang menyatakan bahwa produk asuransi yang halal adalah yang murni tabarru". ${ }^{31}$ Dalam seminar "Syariah Untuk Semua" yang diadakan oleh Prudential Life Assurance (Prudential Indonesia) di Jakarta, Syakir Sula mengatakan "Mereka mengganggap asuransi sekaligus investasi (bisnis), haram, walaupun ini adalah produk asuransi syariah, yang tidak mengenal bunga, judi, dan gharar".

Kedua asuransi syariah ini diikat dengan perjanjian (akad) yang berbeda. Bila tujuannya hanya ingin mendapat manfaat asuransi umum (bukan bisnis) maka menggunakan akad tabarru'. Bila membuat asuransi dengan tujuan investasi maka menggunakan akad tijarah dan bisnis yang diasuransikan diikat dengan akad mudharabah, (Syakir Sula). Ia juga mengatakan, asuransi sekaligus investasi itu juga mengandung unsur tabarru' (tolong menolong). Unsur tabarru' itu menempel pada produk tersebut. Dalam

\footnotetext{
${ }^{31}$ Syula, majalah Asuransi Syariah
} 
hukum fiqih, akad tijarah dan mudharabah jika bertemu dengan akad tabarru', maka hukumnhya halal. Menurutnya, masyarakat perlu memahami bahwa asuransi syariah itu, baik murni tabarru' maupun asuransi sekaligus investasi, sama-sama halal.

Otentisitas asuransi syariah di Indonesia dibutuhkan dengan memperkuat seluruh produk-produk asuransi syariah agar berjalan sesuai dengan ketentuan syariah, dalam hal ini peran Dewan Pengawas Syariah (DPS) menjadi bagian penting dalam melakukan pengawasan yang ketat terhadap jalannya aktivitas lembaga asuransi syariah. DPS adalah badan independen yang ditempatkan oleh Dewan Syariah Nasional (DSN) pada lembaga keuangan syariah. Peranan Dewan Pengawas Syariah (DPS) sangat strategis dalam penerapan prinsip syariah dan menurut DSN-MUI No. Kep-98/MUI/2001 bahwa DSN memberi tugas kepada DPS yakni: melakukan pengawasan secara periodik, mengajukan usul-usul pengembangan, melaporkan produk dan operasionalnya sekurang-kurangnya dua kali dalam satu tahun anggaran, serta merumuskan permasalahan yang memerlukan pembahasan dengan DSN. ${ }^{32}$

Sehingga, asuransi syariah menjadi sebuah solusi untuk menjawab kebutuhan kaum Muslim akan pentingnya perencanaan masa depan. Dalam hal ini asuransi syariah mencangkup sebuah transaksi bisnis yang halal dengan akad-akad bebas dari unsur maisir, gharar dan riba. Perusahaan asuransi atau takaful menerima amanah dari peserta untuk melaksanakan kesepakatan saling menanggung atas resiko yang diderita oleh peserta. Dengan prinsip syariah sebagaimana yang sudah dipaparkan sebelumnya, maka berbagai keberatan yang dihadapkan kepada asuransi syariah menjadi tidak ada. Begitupula ketidakpastian (gharar), perjudian (maysir), dan riba, akan hilang dengan sendirinya. ${ }^{33}$

Akan tetapi, dalam implementasinya tetap diperlukan al-ikhtiyat (kehati-hatian) untuk mengoperasikan asuransi syariah, sehingga prinsip dasar syariah dapat dijalankan dalam muamalat asuransi syariah di Indonesia. Dengan demikian konsep asuransi itu sendiri tidak bertentangan dengan semangat syariah.

\footnotetext{
${ }^{32}$ Andrian Sutedi, Passar Modal Syariah, (Jakarta: Sinar Grafika, 2011), h. 256.

${ }^{33}$ Abdul Rahman Gazaly, et.al, Fiqh Muamalah, (Jakarta: Perdana Media Group, 2010), h. 242-243.
} 
Hanya saja, asuransi syariah di Indonesia diatur bersama dengan asuransi konvensional dalam undang-undang No.40 tahun 2014 tentang perasuransian. Kondisi perundang-undangan tentang asuransi syariah yang di integrasikan dengan asuransi konvensinal merupakan kondisi yang tidak ideal jika mengingat perbedaan-perbedaan prinsipil diantara keduanya. Oleh karena itu, penerapan asuransi syariah tidak semata-mata membutuhkan payung hukum tetapi juga aturan yang jelas dan khas. Sehingga lembaga asuransi syariah diharapkan dapat mengembangkan sebuah manajemen asuransi secara mandiri, terpadu dan profesional serta tidak menyalahi aturan dasar yang telah digariskan dalam ajaran syariah Islam.

\section{Kesimpulan}

Dari pemaparan yang dilakukan, dapat disimpulkan:

Uraian tentang asuransi syariah dikemukakan dalam Fatwa DSN-MUI No. 21/DSN MUI/X/2001 tentang pedoman Umum Asuransi Syariah. Dalam ketentuan umum poin 1 disebutkan: "Asuransi syariah (ta"min, takaful, atau tadhamun) adalah usaha saling tolong menolong di antara sejumlah orang/pihak melalui investasi dalam bentuk asset dan/atau tabarru' yang memberikan pola pengembalian untuk menghadapi risiko tertentu melalui akad (perikatan) yang sesuai dengan syariah". Asuransi syariah menggunakan akad takaful, tabarru' dan ijarah, dengan system sharing of risk (saling menanggung antara satu peserta dengan peserta lainnya (ta'awum). Untuk kemurnian penerapan asuransi syariah di Indonesia dibutuhkan dengan memperkuat seluruh produk-produk asuransi syariah agar berjalan sesuai dengan ketentuan syariah, dalam hal ini peran Dewan Pengawas Syariah (DPS) menjadi bagian penting dalam melakukan pengawasan yang ketat terhadap jalannya aktivitas lembaga asuransi syariah.

Asuransi syariah menjadi sebuah solusi halal untuk menjawab kebutuhan kaum Muslim akan pentingnya perencanaan masa depan. Melalui UU No. 40 tahun 2014 tentang perasuransian, pemerintah Indonesia telah memberikan payung hukum bagi asuransi syariah, akan tetapi pada sisi lainnya, pengaturan asuransi syariah di Indonesia masih terintegrasi dalam ketentuan asuransi konvensional, karenanya, diperlukan aturan yang bersifat khusus untuk mengatur asuransi syariah. Sehingga lembaga asuransi syariah 
diharapkan dapat mengembangkan sebuah manajemen asuransi secara mandiri, terpadu dan profesional serta tidak menyalahi aturan dasar yang telah digariskan dalam ajaran syariah Islam.

\section{Daftar Pustaka}

Abdul Hamid, Mohammad, et.al. The Ownership of Islamic Insurance (Takaful) in Malaysia, Inernational Journal of Advances in Management and Economics, Vol.2, Issue 6, Nov-Dec. 2013.

Ali, H. \& Am, Asuransi dalam perspektif hukum islam . Jakarta: Kencana, 2004.

Anis, Ibrahim, Al-Mu“jam Al-Wasith, Juz I, cet. II, Kairo: Dar Ihya ${ }^{e e}$ At-Turats Al-,Arabiy, 1972.

Burhanuddin, Aspek hukum lembaga keuangan syariah edisi I. Yogyakarta: Graha ilmu. 2010.

DSN, Fatwa MUI NO. 21 DSN/MUI/X/2001 Tentang Pedoman Umun Asuransi Syariah.

Faruq Nabhan, Muhammad, al-Madkhal Li al-Tasyri" al-Islam, Bairut: Libanon, Dar al Qalam: 1981. Dalam Abdul Manan, Reformasi hukum Islam di Indonesia, Jakarta: Rajawali Press, 2005.

Firdaus, Muhammad, dkk, Sistem Operaassional Asuransi Syariah, Jakarta: Renaisan, 2005.

Gazaly, Abdul Rahman, et.al, Fiqh Muamalah, Jakarta: Perdana Media Group, 2010.

Hasan Ali, AM, Asuransi dalam Perspektif Hukum Islam, Suatu Tinjauan Analisis Historis, Teoritis dan Praktis, Jakarta: Pernada Media, 2004.

Himpunan Fatwa DSN Edisi Kedua Tahun 2003, dalam H. A. Djazuli, Kaidah-kaidah Fikih, Hukum Islam Menyelesaikan Masalah yang Praktis, Jakarta: Kencana Prenadamedia Group, 2006.

Husein, Rahmad, Asuransi Takaful Selayang Pandang dalam Wawasan Islam dan Ekonomi, Jakarta:

Lembaga Penerbit FE-UI, 1997.

Ichman Sam, M, dkk, Himpunan Fatwa Dewan Syari"ah Nassional, Edisi Ketiga Jakarta: 
DSN MUI, 2006.

Iqbal, Muhaimmin, Asuransi Umum Syariah dalam Praktik, Jakarta: Gema Insani Press, 2006.

Kutub, Muhammad, Ekonomi Syariah dan Lingkungan Hidup (Studi Analisis Fatwa DSNMUI tentang Pasar Modal dan Pedoman Umum Penerapan Prinsip Syariah di Bidang Pasar Modal), tesis, Yogyakarta: UIN Sunan Kalijaga, 2017.

RI, Departemen Agama, Al-Qur"an dan Terjemah, Bandung: Sygma, 2007.

S, Anwar, Hubungan Perjanjian Syariah, Jakarta: PT.Raja Grasindo Persada, 2007.

Soemitra, Andri, Bank \& Lembaga Keuangan Syariah, Jakarta: Kencana, 2009.

Sofiniyah \& Ghufroon, Sistem operasional asuransi syariah, Jakarta: Renaisan, 2005.

Subekti, R dan Tjitrosudibio, R., Kitab Undang-Undang Hukum Dagang, Jakarta: PT Pradnya Paramita, 1985.

Sumitro, Warkum, Asas-Asas Perbankan Islam dan Lembaga-Lembaga Terkait di Indonesia, Jakarta: Raja Grafindo Persada, 1997.

Sustanti, Jeni, Pengelolaan Lembaga Keuangan Syariah, Malang: Empat Dua, 2016.

Sutedi, Andrian, Passar Modal Syariah, Jakarta: Sinar Grafika, 2011.

Syula, Muhammad Syakir, Asuransi Syariah (Life and Generel): Konsep dan Sistem

Operasional, Cet I, Jakarta: Gema Insani Pres, 2004.

Undang-undang No.40 Tahun 2014 Tentang Perasuransian.

Wirdyaningsih, dkk, Bank Dan Asuransi Islam di Indonesia, Jakarta: Kencana, 2005.

www.ojk.go.id diakses 6 November 2018.

Z Ali, Hukum asuransi syariah, Jakarta: Sinar Grafika, 2008. 